\title{
Government Amnesty Programme and Peace Efforts in the Niger Delta Region: An Analysis of Newspapers' Coverage
}

\author{
Adeyemi Aderogba, PhD \\ Osun State University, Nigeria
}

doi: 10.19044/esj.2016.v12n20p26 ＵRL:http://dx.doi.org/10.19044/esj.2016.v12n20p26

\begin{abstract}
Nigeria has undergone not a few crises since the country gained political independence from Great Britain in 1960. One of the current crises is the agitation of the youths of the oil-rich Niger Delta region for the control of oil and gas resources located in their region. In a bid to stem down the tide of violent activities and its attendant obstruction of the economic development of not only the region but also that of the nation at large, the government introduced what it termed "Presidential Amnesty Programme". This paper examined the newspapers' coverage of the situation in the Niger Delta region at a period considered the peak of the crisis, that is 2007 and 2009 as well as the coverage of the situation during the amnesty period (from $6^{\text {th }}$ August to $4^{\text {th }}$ October 2009). Content analysis was employed for this study. The study period was divided into two, that is, pre- amnesty period and amnesty period. Two popular national daily newspapers were examined, that is the Punch and the Guardian newspapers. A total number of three hundred and two copies of the two newspapers selected for the study were content analyzed. One hundred and eighty two were examined for the first period and one hundred and twenty copies were looked into for the second period. Social responsibility theory was considered relevant to the study. It was discovered that violent activities were well pronounced before the commencement of amnesty programme. 47.8 percent of the newspapers content on the region for the period was on violent activities such as vandalism of oil installations, violent attacks on oil workers and kidnappings. However, "Presidential Amnesty Programme" significantly reduced tension as well as crime in the region. Only 13 percent of all the stories published in the two newspapers during the amnesty programme were on violence. Huge numbers of the former militants (about 30,000) embraced reconciliation and rehabilitation. Amnesty programme so far has proved to be huge success.
\end{abstract}


Keywords: Violent activities, amnesty programme, rehabilitation, reconciliation, peace building

\section{Introduction}

Amnesty policy is not new to the world. According to Ikelegbe \& Umokoro 2014:20) cited in Imongan (2015:40): the word amnesty is a Greek word derived from "amnestia" which is an act of grace by which the supreme power in a state restores those who may have been guilty of any offence against it to the position of innocent persons (Novus homo) and it includes more than pardon, in as much as it obliterates all legal remembrances of the offences. It is also the act of authority by government in which pardon is granted to persons especially for political offences, and release from guilt or penalty of an offence.

There are various kinds of amnesty programmes. There is what is called tax amnesty which provides delinquent taxpayers with a one-time opportunity to clear their accounts by paying taxes and interest without being subject to criminal penalties (Parle, William M., and Mike W. Hirlinger. 1986, Alm, J., McKee, M., \& Beck, W.1990, Joulfaian, D.1988). Tax amnesty could assist governments' revenue generation drive and it may at the same time end up to anger law abiding tax payers who dislike seeing tax defaulters given tax breaks (Leonard, H. B., \& Zeckhauser, R. J.1987). Amnesty policy was aimed at reducing over-crowded prison in France. Such a policy has however become regular policy of the governments around the world. Lévy, R. (2007:551) asserts:

In the past amnesties were used as instrument of national reconciliation after political crises; they are now a regular feature of presidential elections, aimed at ordinary crime.

There is also what is called housing amnesty programme which aims at providing affordable housing for the citizenry. ( Ungerleider 1998).

Amnesty policy is not entirely new to Nigerians but the dimension the current amnesty programme has taken as well as the huge cost implication is completely new. The government of Nigeria decided to introduce the policy in order to help eradicate militancy in the oil - rich Niger Delta region.

\section{Anatomy of the Niger Delta Conflict and Presidential Amnesty Programme}

Federal government amnesty programme in the oil-rich Niger Delta region of Nigeria is a programme designed by the government to address youths restiveness in the region. Petroleum which happens to be the backbone of Nigerian economy today, was discovered in 1956 and with the commencement of exploration of the resource in Oloibiri in 1959, Nigeria 
entered into a new era of national development. Unfortunately, the initial optimism that greeted the discovery of crude oil in Nigeria didn't last. Neglect of oil producing communities by successive governments coupled with unprecedented environmental degradation caused by oil spillage, gas flaring and other ecological issues have adversely affected the nation.

Ejovi and Ebie (2013:130) citing Niger Delta Natural Resources Damage Assessment and Restoration Project (2006), affirm that:

The environmental impact of oil exploration in the Niger Delta region of Nigeria has contributed in no-small measures to the destruction of the fragile ecosystem,

The region is considered to be one of the world's most severely petroleum impacted ecosystems and one of the 5 most petroleum-polluted environment in the World.

Despite the fact that the Nigerian government derives 70 percent of its revenue and up to 90 percent of its foreign earnings from crude oil exploration from the Niger Delta, poverty level in the region is ranked among the highest in Nigeria. According to (Watts, 2008) cited in Oluduro and Oluduro (2012:49):

Almost 90 per cent of the local inhabitants of the Niger Delta fall below the poverty line of $\$ 1$ dollar per day as they depended on the aquatic resources for their livelihoods.

Catastrophic ecological situation of the Niger Delta region, which a direct negative effect of crude oil exploration activities in the region, has virtually destroyed the area's aquatic resources.

Crude oil exploration brought countries like Qatar, Saudi Arabia, United Arab Emirates wealth and prosperity but for Nigeria, the biggest oil producing country in Africa, crude oil exploration has brought the country curse rather than blessing. Not much of the money derived from the sales of crude oil was used for the development of the country as a result of corruption.

Late Chinua Achebe, asserted that Nigeria lost as much as \$400 billion in forty years to corruption. (The Punch, 12 $2^{\text {th }}$ January, 2012 pg 3). Series of corruption scandals that are being exposed in Nigeria by President Muhammadu Buhari is a clear indication that the figure could even be much higher than that.

Instead of addressing the issue of under development of oil producing area and official corruption, Nigerian maximum ruler, late General Sanni Abacha decided to hang environmental activists from the Niger Delta region - Ken Saro - Wiwa and eight of his kin-men. The brutal killing of these Nigerians irked the people of the region and sparked off violent agitation. The situation in the Niger Delta region till date is anything but peaceful. 
Watts (2006) is of the opinion that Nigerian situation is: an exemplar of the failure of oil-based development. Central to this analysis is the emergence of new forms of armed insurgency in the oil producing Niger Delta that has rendered the entire area virtually ungovernable, increasingly so since the emergence in late 2005 of a new armed group MEND (the Movement for the Emancipation of the Nigeria Delta).

The government of Nigeria could no longer ignore the Niger Delta question mostly because over the years, crude oil gradually became the backbone of Nigerian economy by giving the nation about ninety percent of its external earning. At the peak of youth restiveness in the Niger Delta, crude oil production fell to all time low of 700,000 barrels per day. This is because the Niger Delta youths actively engaged in vandalism of oil installations, kidnappings of oil workers, bunkering activities and other vices thereby disrupting exploration process in the region. After much deliberation, the government of Late Umar Ya'Adua decided to adopt a new policy called "'Presidential Amnesty Programme" that would help to proffer solution to the menace of violence in the Niger Delta. Imongan (2015:39) asserts that:

One of the efforts by Late President Yar'Adua administration was his good intention to address the agitation in the region by granting unconditional amnesty to militants hoping the gesture would effectively stop the ranging restiveness in the oil bearing area. The amnesty was announced on the 25th June, 2009 with an expiration of 60 days period which was expected to run from August 6 to October 4 ,

The programme initially proved to be monumental success as peace was restored to the Niger Delta. Crude oil production reached it all time height of 2.6 million barrels per day. Imongan (2015:40) confirms that:

The Federal Government through the Presidential Amnesty Programme is to manage, supervise and implement the amnesty programme. At the end of the 60 days period on October 4, 2009, a total of 20,192 repentant militants surrendered their arms and ammunitions to the Federal Government and accepted the programme. In November 2010, another 6,166 ex-agitators were enlisted into the PAP this constituted the second phase and brought the number of persons enlisted to 26,358. More importantly, in 2012 the Federal Government also approved the inclusion of 3,642 transformed ex-agitators who were excluded in both the first and second phases, bringing the total number of ex-militants to 30,000 that have so far embraced and accepted the amnesty programme proclaimed by the Federal Government. 


\section{Method}

This paper examined the newspapers' coverage of the situation in the Niger Delta region at a period considered the peak of the crisis, that is, 2008 as well as the coverage of the situation during the amnesty programme (from $6^{\text {th }}$ August to $4^{\text {th }}$ October 2009). Content analysis was employed for this study. The study period was divided into two, that is, pre- amnesty period and amnesty period. Two popular national daily newspapers (the Punch and the Guardian) were randomly selected and examined. Year 2008 was randomly selected and considered for analysis since the peak of the agitation actually commenced between 2007 and first half of 2009. 2008 was subdivided into four quarters and from which the last quarter of 2008 was randomly selected. Altogether 182 issues of the two selected newspapers were examined for the pre-amnesty period or "Study Period I".

Amnesty period or "Study Period II" began on 6th August and ended $4^{\text {th }}$ October 2009. 120 copies of the two newspapers were content analyzed for the period. Altogether, a total of 302 issues of the two newspapers selected for the study were thoroughly examined.

As for the status of the two newspapers, incidentally, the Punch and the Guardian newspapers are considered to be two of the most popular newspapers in Nigeria.

\section{Scope of the study}

The two periods covered by the study are:

1. The peak of youth restiveness in the Niger Delta, (pre-amnesty period) that is, last quarter of 2008.

2. Amnesty period i.e. August 6, to October 4, 2009.

\section{Study Universe}

For the "Study Period I", a total of 182 issues of the two selected newspapers were examined out of which 232 stories were selected for the study. As for the "Study Period II", 120 issues were examined out of which 185 stories were considered relevant to the study.

\section{Objectives of the study}

This study seeks to achieve the following objectives:

1. To discover the most dominant issues covered by the press during the study period.

2. To determine the level of violence reported by the press during the period.

3. To find out the tone of materials published in the selected newspapers. 


\section{Research questions}

The following questions were therefore answered:

1. What were the most dominant issues covered by the press during the study period?

2. What was the level of violence reported by the press during the study period?

3. What was the slant of the materials published by the newspapers selected for the study?

\section{Operational Definitions}

Violence: Activities of the militant groups in the Niger Delta region of Nigeria, these include vandalism of oil and gas installations, bunkering, kidnappings etc.

Peace Building efforts: These include any piece of action undertaken to bring about peace in the troubled Niger Delta region such as reconciliation between the Federal Government and the militants, disarmament and demobilization of the militants.

Rehabilitation: This is the efforts been made to resettle repentant militants, it involves reintegration of the militants.

Oil and Gas Business: Investment in oil and gas exploration, exportation and importation of refined products by multinational oil companies or any other investors.

Environmental Degradation: Oil spillage, gas flaring, water pollution and soil pollution etc.

Developmental Efforts: Efforts been made by both government and multinational companies in order to develop the Niger Delta region.

Prominence: This is basically about the placement of news stories on different pages of newspaper. Stories on the front page and back page are considered more prominent than those buried in the inside page.

Genre: This is the story type such as news story, feature story/opinion, editorial and interview.

Slant: This is the tone of news stories towards the government. The slant could either be favourable, unfavourable and neutral.

\section{Theoretical Framework}

The theory considered most appropriate for this study is Social Responsibility Theory because the theory fundamentally addresses the role the media practitioners should play in the society. Emphasizing on this fact, a communication scholar, Denis McQuail expresses the opinion that the media should accept to fulfill certain obligations to society. McQuail (1993:117):

These obligations can only be met by setting high 
of informativeness, truth, accuracy, objectivity and

balance. In accepting and carrying out these

obligations, the media should be self-regulating

within the framework of the law and established institutions.

Media practitioners are to focus their attention on the society whenever they are performing their duty of news gathering, processing and dissemination. The question that every practitioner should ask is "whose benefit is the story?" if the answer is the generality of the society, in the interest of peace and progress, then such news item deserves a space. A socially responsible media practitioner cannot propagate any ideology that can destroy the society; he or she would not give undue publicity to terrorism, militancy, cultism etc.

\section{Data presentation}

Table 1 Story genre

\begin{tabular}{|c|c|c|c|c|c|c|c|c|c|c|c|}
\hline \multirow[t]{2}{*}{ Newspaper } & \multirow[t]{2}{*}{ Study Period } & \multicolumn{2}{|c|}{ News Story } & \multicolumn{2}{|c|}{ Feature } & \multicolumn{2}{|c|}{ Editorial } & \multicolumn{2}{|c|}{ Interview } & \multicolumn{2}{|l|}{ Total } \\
\hline & & Freq & $\%$ & Freq & $\%$ & Freq & $\%$ & Freq & $\%$ & Freq & $\%$ \\
\hline The Guardian & Study Period I & 93 & 40.1 & 21 & 9 & 2 & 0.86 & 4 & 1.7 & 120 & 51.7 \\
\hline & Study Period II & 59 & 31.9 & 7 & 3.7 & 0 & 0 & 9 & 4.9 & 75 & 40.5 \\
\hline The Punch & Study Period I & 85 & 36.6 & 42 & 18.1 & 1 & 0.4 & 5 & 2.2 & 112 & 48.3 \\
\hline & Study Period II & 99 & 53.5 & 5 & 2.7 & 1 & 0.5 & 5 & 2.7 & 110 & 59.4 \\
\hline
\end{tabular}

Table 1 reveals that the genre of most of the published materials in the selected newspapers was news story. In Study Period I, 40.1 percent of all the stories considered relevant to Niger Delta were news story, for the Punch newspaper, 36.6 percent of the materials were news story. In the Study Period II, 31.9 percent of all the materials published in the Guardian newspaper were news story.

Table 2 Story Source

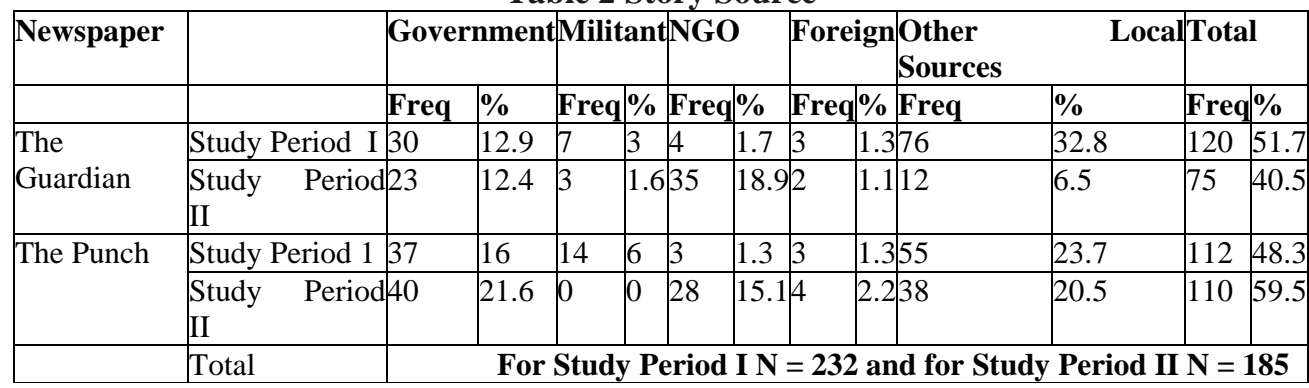

According to table 2, stories gathered from sources other than government dominated the pages of the newspapers selected for this study with their news. For the Study Period I, other local sources' share of the stories published in the Guardian were 32.8 percent, government's share was 
12.9 percent, 3 percent of the information came from the militants. Overwhelming majority of the stories published in the Punch, that is 56.5 percent came from other local sources, just 16 percent of the materials were sourced from government.

As shown in Table 2, majority of the stories published by Guardian newspaper during the Study Period II, that is 18.9 percent were sourced from the NGO, materials gathered through government sources were 12.4 percent. For the Punch, stories from government sources constituted the majority, that is 21.6 percent, followed by stories from other local sources with 20.5 percent.

Table 3 Slant

\begin{tabular}{|c|c|c|c|c|c|c|c|c|c|}
\hline Newspaper & & $\begin{array}{l}\text { Favou } \\
\text { Gove }\end{array}$ & & to $\mathrm{Ne}$ & tral & $\begin{array}{l}\text { Unfa } \\
\text { Gove }\end{array}$ & & to Tota & \\
\hline & & Freq & $\%$ & Fre & $\%$ & Freq & $\%$ & Freq & $\%$ \\
\hline $\begin{array}{l}\text { The } \\
\text { Guardian }\end{array}$ & $\begin{array}{|ll|}\text { Study } & \text { Period } \\
1 & \end{array}$ & 35 & 15.1 & 23 & 9.9 & 62 & 26.7 & 120 & 51.7 \\
\hline & $\begin{array}{|ll|}\text { Study } & \text { Period } \\
2 . & \\
\end{array}$ & 24 & 13 & 37 & 20 & 14 & 7.6 & 75 & 40.5 \\
\hline The Punch & $\begin{array}{ll}\text { Study } & \text { Period } \\
1 . & \\
\end{array}$ & 22 & 9.5 & 27 & 11.6 & 63 & 27.2 & 112 & 48.3 \\
\hline & $\begin{array}{ll}\text { Study } & \text { Period } \\
2 . & \end{array}$ & 37 & 20 & 58 & 31.4 & 15 & 8.1 & 110 & 59.5 \\
\hline & Total & & Stu & iod & $=2$ & 32 a & dy $P$ & I $\mathrm{N}=18$ & \\
\hline
\end{tabular}

Table 3 indicates that for the study period 1, majority of the materials published in the Guardian newspaper, that is 26,7 percent, were negative towards the government, the figure for the Punch newspaper was 27.2 percent.

For the Study Period II, i.e. amnesty period, the situation changed in favour of the government. Only 7.6 percent of the stories published in the Guardian were negative towards the government, 20 percent were neutral, 13 percent were favuorable towards the government. For Punch, 8.1 percent were negative, 31.4 percent were neutral and 20 percent were in favour of the government.

Table 4 Prominence

\begin{tabular}{|c|c|c|c|c|c|c|c|c|}
\hline \multirow{2}{*}{ Newspaper } & & \multicolumn{2}{|c|}{ Front Page } & \multicolumn{2}{|c|}{ Inside Page } & \multicolumn{2}{|c|}{ Back Page } & \multirow{2}{*}{\begin{tabular}{|l|l|}
\multicolumn{2}{|l|}{ Total } \\
Freq & $\%$ \\
\end{tabular}} \\
\hline & & Freq & $\%$ & Freq & $\%$ & Freq & $\%$ & \\
\hline \multirow[t]{2}{*}{ The Guardian } & Study Period I & 21 & 9 & 83 & 35.8 & 16 & 6.9 & \begin{tabular}{|l|l|}
120 & 48.3 \\
\end{tabular} \\
\hline & Study Period II & 17 & 9.2 & 51 & 27.6 & 7 & 3.8 & 40.5 \\
\hline \multirow[t]{3}{*}{ The Punch } & Study Period I & 9 & 3.9 & 101 & 43.5 & 2 & 0.8 & \begin{tabular}{|l|l|}
112 & 48.3 \\
\end{tabular} \\
\hline & Study Period II & 11 & 5.9 & 99 & 53.5 & 0 & 0 & \begin{tabular}{|l|l|}
110 & 59.5 \\
\end{tabular} \\
\hline & Total & \multicolumn{7}{|c|}{$\begin{array}{l}\text { For Study Period I N = } 232 \text { and for } \\
\text { Study Period II N = 185 }\end{array}$} \\
\hline
\end{tabular}


Table 4 shows that Niger Delta problems were given prominence by Nigerian press. In Guardian newspaper and for the study period I, 9 percent of all the stories that were considered relevant to Niger Delta issues hit the front page 6.9 percent made the back page. For the Punch newspaper, only 3.9 percent of the materials appeared on the front page

During the study period II, 9.2 percent of the materials were front page stories; 3.8 percent appeared on the back page. The Punch newspaper had 5.9 percent of the materials on its front page.

Table 5 Theme of story

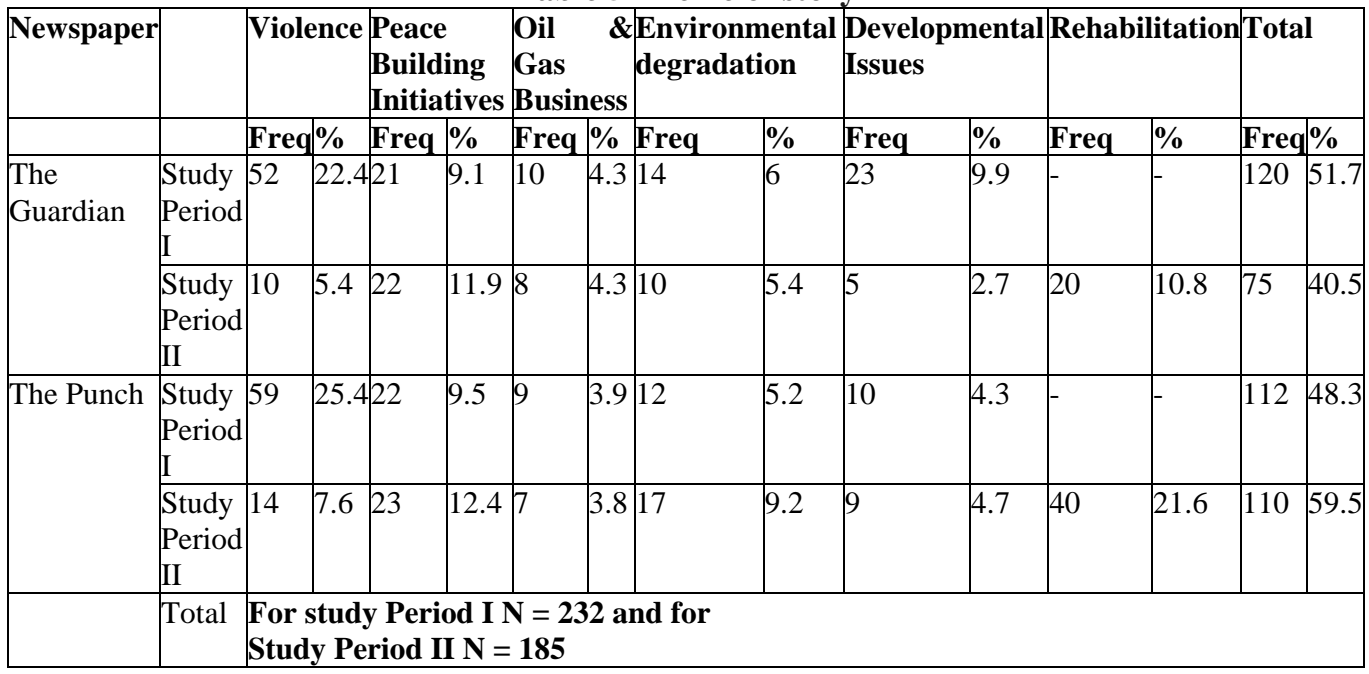

Table 5 contains data on themes derived for this study. Majority of the stories during the Study Period I were on various forms of violence; 22.4 percent of all the publications in the Guardian were on violence, 9. 9 percent were on developmental issues, 9.1 percent were on peace building initiatives.

For the Study Period II, peace building initiatives and rehabilitation dominated the pages of Guardian newspaper with 11.9 percent and 10.8 percent respectively, only 5 percent of the materials were on violence. Overwhelming majority of the materials published in the Punch, that is, 21.6 percent were on rehabilitation; this was followed by peace building and environmental degradation with 12.4 and 9.2 respectively. Materials on violence dropped to 7.6 percent.

\section{Discussion}

Three research questions were raised for this study; an attempt is made to answer the questions.

Research question 1: What were the most dominant issues covered by the press during the study periods? 
Table 5 provides answer for this question, during the Study Period I, newspaper pages were dominated by stories on violent activities within the Niger Delta region, 47.8 percent of all the stories relevant to that region were on violence. This finding corroborates the claims of a number of researchers on Niger Delta problems (Ugwu \& Oben 2010, Ejovi \& Ebie 2013). The second most important theme during the "Study Period I" is peace building efforts with 18.6 percent of all the relevant materials published, materials on environmental issues formed 14.2 percent of the publications.

For the Study Period II, rehabilitation of the militants was the most important issue in the press with 32.4 percent of all the materials on Niger Delta, followed by peace building efforts with 24.3 percent.

Interestingly, violent related issues were so negligible during the Study Period II. Only 13 percent of the publications on Niger Delta region were on violence.

Research question 2: What was the level of violence reported by the press during the study period?

Data presented in Table 5 above shows that violence was so common in the region. As much as 47.8 percent of the stories considered relevant to this study were on violence in the region.

However, the situation changed during the Study Period II, rehabilitation became the reigning topic with 32.4 percent of the stories, (that is, the highest numbers of stories), were on that topic. Stories on violence declined to just 13 percent.

Research question 3: What was the slant of the materials published by the newspapers selected for the study?

Table 3 provides answer to this question, for the "Study Period I", data on Table 3 shows that 53.9 percent of the stories were so negative towards the government. Obviously, the situation changed in favour of the government during the "Study Period II", as just 15.7 percent of the publications were negative towards the government. Amnesty programme was well received by all and sundry.

Table 3 also indicates that for the "Study period I", majority of the materials published in the Guardian newspaper, that is 26,7 percent, were negative towards the government, the figure for the Punch newspaper was 27.2 percent.

For the "Study Period II", i.e. amnesty period, the situation changed in favour of the government. Only 7.6 percent of the stories published in the Guardian were negative towards the government, 20 percent were neutral, 13 percent were favuorable to the government while 8.1 percent were negative, 31.4 percent were neutral and 20 percent were favourable to the government. 


\section{Conclusion}

Niger Delta situation is a kind of tragedy of sort. It is a failure of governance, a result of years of maladministration, colossal mismanagement of human and material resources by successive governments. The people of the area no doubt have legitimate right to protest but violence is clearly not a better option. Findings of this study reveal that major problem can be tackled through dialogue.

In 2007/2008, there was violence everywhere in the region, a situation that adversely affected the economy of Nigerian state but as soon as there was a genuine dialogue between the government of Late President Umar Yar' Adua, and Niger Delta people, the youths sheathed their swords and embraced peace. It is therefore necessary to continue to follow the path of dialogue.

Unfortunately, seven years into the amnesty programme, there is that fear in many quarters of whether or not the amnesty policy of Nigeria government would be capable of addressing numerous problems of the Niger Delta region as a new militant group called "Niger Delta Avengers (NDA)" is born.

\section{Recommendations}

1. The Federal Government of Nigeria enjoyed the good will of the people of the Niger Delta region when the Presidential Amnesty Programme began, government should build on this by implementing all the agreements reached during the negotiation. That is the only way by which peace and progress can return to the Niger Delta in particular and Nigeria in general.

2. Federal Government should communicate more with the people, data on table 2 show that 28.9 percent of the stories published during the "Study Period I" came from the government sources while as much as 56.5 percent came from other local sources.

3. The media in the country give undeserved most probably "free publicity" to militants and terrorists by publishing stories that are sometimes positive towards the terrorists. As much as 9 percent of the stories published by the selected newspaper during the "Study Period I" were from the militants. This should be absolutely discouraged.

\section{References:}

Alm, J., Mckee, M., \& Beck, W.. (1990). Amazing Grace: Tax Amnesties and Compliance. National Tax Journal, 43(1), 23-37. Retrieved from http://www.jstor.org/stable/4178882 
Ejovi Austine \& Ebie .C. Sunday (2013). Niger Delta: A Critical Appraisal of the Amnesty Programme and Social Political Development in Nigeria. Research on Humanities and Social Sciences . IISTE Vol.3, No.22, pg 130. Imongan Ernest Omokhoa (2015). Amnesty Programme In Nigeria: Understanding Justice And Equity In The Niger Delta Region International Journal of Public Administration and Management Research (IJPAMR), Vol. 3, No 2, p 39.December, 2015. Retrieved June 26, 2016 from http://www.rcmss.com

Joulfaian, D.. (1988). Participation In Tax Amnesties: Evidence From A State.Proceedings of the Annual Conference on Taxation Held Under the Auspices of the National Tax Association-tax Institute of America, 81, 128133. Retrieved from http://www.jstor.org/stable/42912201

Leonard, H. B., \& Zeckhauser, R. J. (1987). Amnesty, Enforcement, and Tax Policy. Tax Policy and the Economy, 1, 55-85. Retrieved from http://www.jstor.org/stable/20061763

Lévy, R.. (2007). Pardons and Amnesties as Policy Instruments in Contemporary France.Crime and Justice, 36(1), 551-590. Retrieved from http://doi.org/10.1086/592811 McQuail, D. (1993). Mass communication theory: An introduction ( ${ }^{\text {nd }}$ ed.). New Delhi:Sage Publication.

Oluduro. O and Oluduro. F. O. (2012). Nigeria: In Search of Sustainable Peace in the Niger Delta through the Amnesty Programme Journal of Sustainable Development; Vol. 5, No. 7, pg 48.

Parle, William M., and Mike W. Hirlinger. (1986). Evaluating the Use of Tax Amnesty by State Governments. Public Administration Review 46 (3). [American Society for Public Administration, Wiley]: 246-55. doi:10.2307/3110440.

Siri Aas Rustad and Helga Malmin Binningsbø (2012). A price worth fighting for? Natural resources and conflict recurrence, Journal of Peace Research, Vol. 49, No. 4, pp. 531-546 Sage Publications Ltd. Retrieved June 18, 2016 from http://www.jstor.org/stable/41721605

Ugwu. C. E \& Oben. A. N (2010). An Assessment Of The Amnesty Programme Implementation In The Niger Delta Of Nigeria (2009-2011), Bassey Andah Journal of Cultural Studies, Vol. 13. Retrieved from https://www.google.com.ng/webhp?sourceid=chrome-instant\&ion=1\&espv=2\&ie=UTF-

8\#q=Bassy+Andah+Journal on June 28, 2016

Ungerleider, R. N.. (1998). Viewpoint: A Call for a Fair Housing Amnesty Program. Journal of Affordable Housing \& Community Development Law, 7(2), 149-153. Retrieved from http://www.jstor.org/stable/25782330

Watts Michael (2008). Imperial Oil. Anatomy of a Nigerian oil insurgency, ERDKUNDE Vol. 62. No. 1 pg 27. 